\title{
PREVENTATIVE MEASURES OF INSURERS AGAINST INSURANCE FRAUD WITH PARTICULAR REGARD TO MOTOR INSURANCE
}

\author{
Samantha Huneberg \\ BCom (Law) LLB LLM \\ Lecturer, University of Johannesburg
}

\section{SUMMARY}

Insurance fraud is prevalent in all spheres of the insurance industry; however, motor vehicle insurance sees a major increase in fraudulent insurance claims. It is for this reason that insurers need mechanisms in place to protect themselves from fraudulent claims by an insured. One of the more common preventative measures that insurers are using to protect themselves is by inserting forfeiture clauses in the insurance contract itself. These clauses aim to protect the insurer against any type of fraudulent claim by the insured. These clauses do, however, also bring a host of issues to the fore; including the fairness of these clauses as against the insured. These clauses do tend to be one-sided and therefore, a proper evaluation of these clauses is necessary to understand the application and effect these clauses can have on both the parties to an insurance contract.

\section{INTRODUCTION}

Due to the fact that the public transport system in South Africa is underdeveloped, many South Africans have to rely on the use of motor vehicles. As motor owners usually have their cars financed, motor insurance is an absolute necessity and the uptake of motor vehicle policies is quite high. As with any other type of property insurance, fraudulent claims are a real concern for South African insurers. Insurance fraud ${ }^{1}$ costs South African insurance companies approximately R4 billion a year, which shows that fraud relating to insurance claims has become a major problem in South Africa. ${ }^{2}$ Both locally and abroad, insurance companies suffer significant

\footnotetext{
Snyman Criminal Law 6ed (2014) 520 defines fraud as "the unlawful and intentional making of a misrepresentation which causes actual prejudice or which is potentially prejudicial to another". Insurance fraud then relates to the unlawful and intentional making of a misrepresentation by the insured which then results in an actual or potential loss for the insurer.

2 Van Niekerk "Fraudulent Insurance Claims" 2000 SA Merc LJ 69; Malherbe "Stretching Solidarity too far: The Impact of Fraud and Corruption on Social Security in South Africa" 2001 Law, Democracy \& Dev 107; "Insurance firms lose R4bn to fraud" 6 November 2013
} 
setbacks due to this increasing problem as fraudulent claims lead to increased premiums. The reason for these hiked premiums is the need for insurers to remain solvent and by ensuring their solvency, insurance companies protect their own interests as well as the interests of other policyholders. It is also in the interest of all policyholders that insurance companies have the resources to combat insurance fraud and to defray other operational risks.

The purpose of this paper is to highlight those preventative measures that are in place to discourage the holders of motor policies from committing fraud. The main focus of the paper is on contractual provisions such as forfeiture clauses that aim to penalize policyholders for committing any type of insurance fraud. The fairness of these clauses and the effect thereof will be weighed against the rights of the policyholders in order to present a balanced view. Ultimately, the various prevalent practices of motor vehicle fraud will be explained in light of the typical kinds of fraud. As a preliminary conclusion, this paper argues that the current state of affairs in South African law relating to motor vehicle fraud is in need of urgent reform.

\section{THE INSURANCE CONTRACT}

The insurance contract is the starting point for any insurance relationship. Consensus on the part of both parties is essential to establish a contractual relationship. Theoretically, standard, short-term insurance contracts should protect both the insured and the insurer and typically various clauses set out the rights of both parties. In reality, however, this is often not the case and the contracts tend to be somewhat one-sided. Inevitably, insurers as the drafters of short-terms insurance contracts often include clauses in insurance contracts as incidentalia that have not been disclosed to the policyholder or if these were disclosed in broad terms, often not explained in detail. ${ }^{3}$ Fraud-related clauses fall into this category, as is elaborated upon below.

To put this statement into perspective: A general definition of insurance is provided in the case of Lake $v$ Reinsurance Corporation $L_{t d}{ }^{4}$ which describes it as a contract between an insurer and an insured, in terms of which the insurer undertakes to render to the insured a sum of money, or its equivalent, on the occurrence of a specified uncertain event in which the

http://www.fin24.com/Economy/Insurance-firms-lose-R4bn-to-fraud-20131106 (accessed 2016-09-15).

3 See Fliptrans CC v S \& P Insurance Advisors (Pty) Ltd t/a McCrystal and Partners; E Solms FAIS 09787/11-12/GP3; Zakhele G Buthelezi v Actebis 406 CC t/a Pro-Brokers; Louis Kempen FAIS 07716/13-14/WC3. In both these cases, the insured vehicles were not fitted with tracking devices and the Ombud ruled in both instances that it was a failure by the broker to advise the complainants about the particular requirement of fitting a tracking device that led to the complainants' losses. See also Jacques du Toit $v$ Barrington Insurance Brokers (Pty) Ltd; John Frayne FAIS 01129/13-14/ GP 3. Although these cases dealt with obligations pertaining to the fitting of tracking devices, they illustrate very clearly that the FAIS Ombud regards the practice of not disclosing certain incidentalia as unfair.

41967 (3) SA 124 (W). 
insured has some interest, in return for the payment of a premium. ${ }^{5}$ The principle of reciprocity entails that both parties have rights and duties and these are specified in the insurance contract. As with any other contract, an insurance contract consists of essentialia, naturalia and incidentalia. ${ }^{6}$

It is generally accepted that the essentialia of an insurance contract are terms of a contract which are essential to the existence of that specific contract. These terms are usually distinctive terms which are used to identify a contract as a specific type of contract. The essentialia of an insurance contract are the following: the insurer will compensate the insured for his/her loss; the insured will pay a premium to the insurer and lastly, the insurer's obligation is dependent on the occurrence of an uncertain future event.

Naturalia are terms which naturally or automatically form part of a contract ex lege, regardless of whether the parties actually agree to their inclusion or not. $^{8}$

Incidentalia typically refer to those clauses that are not naturalia or essentialia, the parties may agree to add these terms into the specific contract and in respect of which the insurer and insured must reach consensus. ${ }^{9}$

As was alluded to above, an example of incidentalia are forfeiture clauses. These clauses generally aim at protecting the insurer's interest. Broadly speaking, a forfeiture clause is a provision in an insurance contract that stipulates that if certain conditions are met, one party will forfeit something to the other. ${ }^{10}$ More specifically, insurers usually rely on a forfeiture clause to exempt them from liability where the insured fraudulently claims for a loss that he has incurred. In short-term insurance, these clauses typically have the effect that an insurer can repudiate an insured's entire claim under the policy, if a part of the claim was exaggerated or lodged fraudulently. ${ }^{11}$

An example of such an express condition in a policy of insurance appeared in the case of Lehmbecker's Earthmoving \& Excavators $v$ Incorporated General Insurances. ${ }^{12}$ The clause in question stipulated as follows:

"If any claim be in any respect fraudulent or intentionally exaggerated or if any fraudulent means or device be used by the insured ... all benefits under the policy shall be forfeited."

\section{Ibid.}

Reinecke, Van Niekerk and Nienaber South African Insurance Law (2013) 75.

Nagel Business Law 4ed (2011) 214.

Reinecke et al South African Insurance Law 183.

Reinecke et al South African Insurance Law 295 fn 13.

Schoeman v Constantia Insurance Company 2003 (2) All SA 642 (SCA) par 2 and 4; Vallee "Would a Plaintiff Forfeit the Entire Claim if the Loss is Fraudulently Exaggerated?" 2003 Deneys Reitz Case Law Update.

11 Reinecke et al South African Insurance Law 75.

121984 (2) All SA 352 (A). 
Being incidentalia, these forfeiture clauses must be expressly contained in the insurance contract in order to have any legal effect and it is imperative to bear this in mind when investigating forfeiture clauses. For example, in the case of Schoeman $v$ Constantia Insurance Company ${ }^{13}$ the appeal court expressly stated that in order for a forfeiture clause to have any legal effect it should be expressly contained in an insurance contract and cannot be an implied term of a contract of insurance. ${ }^{14}$ The SCA stated that forfeiture clauses are not implied by law into contracts of insurance. As masters of their own policies, insurers must include forfeiture clauses in their contracts should they wish to reject a partly fraudulent claim or a claim tainted with fraud. This decision followed the earlier decision in Videtsky $v$ Liberty Life Insurance Association of Africa Ltd. ${ }^{15}$ The latter case held that the insured's fraud was of no consequence as between the insured and the insurer as it had not been directed towards inducing the insurer to pay something it was not in any event obliged to pay. In the Schoeman decision the members of the Court disagreed on whether the inflation of the amount of the claim for a burglary by the policyholder was indeed fraudulent. The members of the Court also held that even if the claim was merely exaggerated by the policyholder, then it did not automatically disqualify the policyholder from claiming what could be proved to have actually been lost.

Dealing with the issue of Roman-Dutch law, the Court observed the following:

"[l]t seems reasonably clear that the sanctions against the presentation of a fraudulent claim in Roman-Dutch law were first, a refusal to allow an insured to profit by the fraud, secondly, a rendering of the insured liable for any loss or expenditure caused by the fraudulent conduct, and thirdly, criminal sanctions entailing rigorous punishment. Forfeiture of the entire claim does not appear clearly as one of the available sanctions."

The Court held that in our law a term cannot be implied ex lege into an insurance contract to the effect that fraud on the part of the insured in pursuing his or her claim will result in the forfeiture of all benefits under the contract. ${ }^{18}$ This clearly follows the Roman-Dutch position. The situation, therefore, is that the treatment of a fraudulently presented claim in our law is not an indication of, and cannot be deployed as the rationale for, a general and broad duty of good faith which continues after the conclusion of the contract. ${ }^{19}$ It is doubtful if an all-embracing general rule of good faith is likely to be recognized in the foreseeable future as part of our common law. ${ }^{20}$

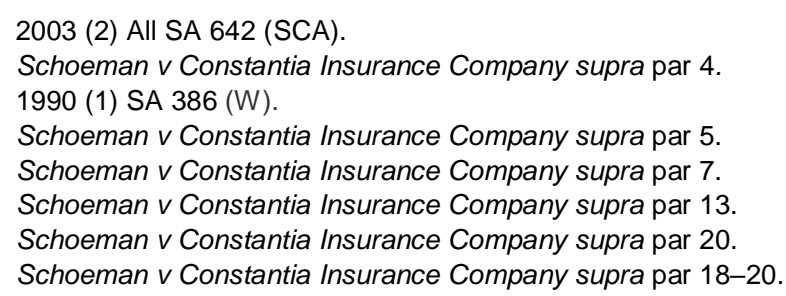




\section{$3 \quad$ FORMS OF INSURANCE FRAUD}

Insurance fraud may take many forms. Van Niekerk refers to three prevalent forms of insurance fraud and says that the distinction between these three forms of insurance fraud is very important as they are each very different. ${ }^{21}$

Generally speaking, there are three different types of fraudulent claims: Firstly, there are fabricated claims. Van Niekerk describes this type of claim as one where:

"[T]he insured suffers no actual loss, or a loss not covered by the insurance contract, and would ordinarily therefore not have been able to recover anything from the insurer. However, the insured fabricates his or her loss, very often causing it, and then fraudulently represents to the insured the loss was caused by a peril covered by the insurance contract".

The second type of insurance fraud highlighted by Van Niekerk refers to exaggerated claims. This may be the most common form of fraud in South Africa. According to Van Niekerk, "it involves an exaggeration of the loss to enable the insured to claim more from the insurer than would otherwise have been possible. Here the insured suffers an actual loss for which he or she is covered, but then claims for a larger amount." ${ }^{23}$ Exaggerated claims are possibly more prevalent due to the fact that it is generally easier to get away with this kind of fraudulent behaviour. Perchance more stringent rules should apply to the claims process in order to avoid the vast amount of exaggerated claims that arise these days. However, the rights of both parties to an insurance contract must always remain in balance and the question is whether forfeiture clauses have a role to play in instances where exaggerated claims are lodged.

The third form of insurance fraud referred to by Van Niekerk is where a valid claim is accompanied by fraudulent means. The author describes this as a type of fraudulent claim that is generally the least serious form of insurance fraud compared to the other types as distinguished. It typically involves "nothing more than a technical or petty fraud designed to ensure that the insured receives that to which the insured is entitled without delay or bother." ${ }^{24}$ In this particular fraudulent claim the insured does suffer a loss but in order to avoid a lengthy query process from the insurer regarding the claim, the insured uses false evidence to substantiate and support his claim. In the case of Videtsky $v$ Liberty Life Insurance Association ${ }^{25}$ the insured plaintiff submitted a completely valid and justified claim for occupational disability benefits in terms of the existing insurance policy. However, in order to advance and speed up her claim the insured forged the signature on a physiotherapist's report. In this case the judge upheld the plaintiff's claim. Judge Fleming held that there was no current South African authority to

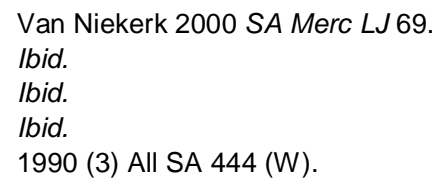


allow a court to find in favour of an implied term in the policy, which would entitle the defendant to repudiate the plaintiff's claim. ${ }^{26}$

It is evident that fraudulent insurance claims take different forms and the very point of departure is to distinguish between the different types of insurance fraud because the consequences and sanctions attached to each type of fraud should ideally be proportionate to the seriousness of the fraud. For example, exaggerated claims are not as serious as fabricated claims, and the sanction attached to fabricated claims should be more serious than a sanction attached to exaggerated claims. But with that being said, an exaggerated claim is still fraud and an appropriate sanction should be given for such fraudulent behaviour. If a claim by the policyholder includes a statement which the claimant knows to be false then that is considered fraud. ${ }^{27}$ However, if a false statement is made inadvertently or carelessly then it is not considered fraud. ${ }^{28}$

\section{FORFEITURE CLAUSES}

\section{General}

It is crucial that insurers have mechanisms in place to protect themselves from fraudulent conduct by an insured. In addition, it is in the best interest of all those who share the risk in any given insurance pool that legitimate claims are paid and fraudulent claims not. There are various ways in which insurers try to protect themselves and one method is the use of forfeiture clauses. The forfeiture clause grants the insurer a significant amount of protection in the instance of fraudulent claims.

These types of clauses which generally provide for the consequences of, and the insurer's rights in consequence of, a fraudulent claim by the insured on his or her insurance contract, have become a prominent feature in most insurance contracts. ${ }^{29}$ The clauses which specifically deal with fraudulent claims can be viewed as a proclamation of the insurer's common-law rights, as they seek to protect the insurer against dishonest policyholders. ${ }^{30}$ The fairness of these clauses is a contentious issue and must be addressed with

26 Videtsky $v$ Liberty Life Insurance Association 1990 (3) All SA 444 (W) 445; Mutual \& Federal Insurance Co Ltd v Oudtshoorn Municipality 1985 (1) SA 419 (A).

27 See fn 3 above; Derry $v$ Peek (1889) 14 App Cas 337.

28 Van Niekerk 2000 SA Merc LJ 69.

29 Schulze 1990 SA Merc LJ 349; Visser 1991 SALJ 385; Van Niekerk 2000 SA Merc LJ 69; Van Niekerk "Continued Confusion about Fraudulent Insurance Claims" 2002 SA Merc LJ 575; Van Niekerk "Some Clarity on Fraudulent Insurance Claims" 2003 SA Merc LJ 305; Jacobs 2006 SA Merc LJ 524; Van Niekerk "Fraudulent Insurance Claims: Implied Term or Duty of Good ... Immateriality of Materiality" 2007 SA Merc LJ 217.

30 Lehmbecker's Earthmoving \& Excavators (Pty) Ltd v Incorporated General Insurances Ltd 1984 (2) All SA 352 (A); where the question was left open whether a clause of this nature is merely declaratory of the legal position in the absence of such a clause. 
reference to the Financial Advisory and Services Act, ${ }^{31}$ the decision in Barkhuizen v Napie ${ }^{32}$ and Napier NO v Van Schalkwyk. ${ }^{33}$

The wording of these forfeiture clauses is also vital. The reason for this is due to the fact that depending on the wording and interpretation of such clauses, they may seek to add to the insurer's rights at common law, sometimes allowing it to avoid liability under circumstances where, at common law, it would not have been permitted either to do so at all or to do so in full. ${ }^{34}$ The wording can inevitably lead to a court either upholding the clause in full or not.

\section{Purpose and effect of forfeiture clauses}

It is essential that we understand the purpose and effect of fraudulent claims clauses such as forfeiture clauses. Therefore, it is firstly necessary to ascertain the position at common law, that is, where a fraudulent claim is brought in terms of an insurance contract that does not contain any contractual provision dealing with the effect of such claims. The common law does not provide for an implied contractual term like a forfeiture clause to automatically form part of an insurance contract. ${ }^{35}$

The point of departure in terms of Roman-Dutch law is that an insured can derive no benefit from his or her fraudulent claim. ${ }^{36}$ Thus, the insured cannot claim more by reason of his or her fraud than he or she is actually entitled to. As a result, the causal effect of the insured's fraud is relevant. This would mean that in terms of Roman-Dutch law, if an insured makes a fraudulent claim then he cannot derive any benefit from such conduct. If an insured has a valid claim and then also puts in an additional fraudulent claim then the common law states that the valid claim will be paid out by the insurer but the fraudulent part of the claim will not. At English law, fraud of any type in connection with an insurance claim - that is, whether the claim is a fraudulently fabricated claim, a fraudulently exaggerated claim, or merely a valid claim accompanied by fraudulent means - tarnishes the contract completely, and therefore results in the forfeiture of, the insured's entire claim. ${ }^{37}$ Therefore, English law states that if any part of a claim is fraudulent then the insurer may forfeit the entire claim. Roman-Dutch law, however, states that the insured will only forfeit that part of the claim that is fraudulent. Clearly, there are differing views on this aspect. South African law needs to be precise as to which legal position it follows. It appears as if our courts do not have a concrete position in this regard and clarity is needed. Insurers

37 of 2002.

2007 (5) SA 323 (CC).

2004 (3) SA 425 (W) 444

Ibid.

Schoeman v Constantia Insurance Company supra par 23

See Van Niekerk Insurance Law in the Netherlands Vol II 1998 993-1012; Van Niekerk 2000 SA Merc LJ 80-83 for further details.

37 Clarke Policies and Perceptions of Insurance Law in the Twenty-First Century (2005) par 27.2C1. 
insert forfeiture clauses in their contracts, which follow the English law position, thus being penal in nature and it must be remembered that the South African common law position is anti-penal in nature. Therefore, there is some uncertainty regarding these clauses and their application.

\section{Proof of fraud}

Another pertinent issue is the burden of proof in fraudulent claims. Fraud is hard to prove. The burden of proving fraud on the part of the insured rests with the insurer. ${ }^{38}$ The insurer must prove, on a balance of probabilities, ${ }^{39}$ that the insured's conduct amounted either to common-law fraud or to fraud as described by the terms of the fraudulent claims clause itself. ${ }^{40}$ The burden is generally an onerous one and our courts have observed that the point of departure has to be that fraud - the insured's intention to deceive and defraud the insurer - is not to be attributed too lightly. ${ }^{41}$ If an insurer suspects fraud then they will require strong proof ${ }^{42}$ thereof and fraud on the part of the insured cannot be presumed, but must be clearly and properly proved. ${ }^{43} \mathrm{~A}$ court must consider each set of facts before it carefully and a proper evaluation of the evidence is required. ${ }^{44}$ It is also due to the fact that fraud is so hard to prove that insurers are reluctant to take on this task and then to rather seek another ground, perhaps a technical issue, for refusing to pay what they believe to be fraudulent claim. ${ }^{45}$

In the case of Renasa Insurance Company Limited $v$ Watson ${ }^{46}$ the Court said the following regarding proof of fraud, "Having regard to the wording of clause 5 (Prevention of Loss - The insured shall take all reasonable steps and precautions to prevent accidents or losses), it is at the very least clear that to require an insured to take steps to prevent a loss, proof of foreseeability of loss eventuating is required. This would require proof that the reasonable person in the position of the insured would have foreseen the

38 Harikasun v New National Assurance Company Limited [2015] JOL 33556 (KZD) 9; Renasa Insurance Company Limited $v$ Watson 32/2014) [2016] ZASCA 13; Clarke Policies and Perceptions of Insurance Law in the Twenty-First Century 206.

39 Clarke Policies and Perceptions of Insurance Law in the Twenty-First Century 206. In English law, it has been said that the more serious the insurer's allegation of fraud, the greater the quality and amount of proof required to sway the probabilities in the insurer's favour; however no different degree of proof is required in civil cases involving fraud than in other civil cases.

40 Shein $v$ Excess Insurance Co Ltd 1912 AD 418; Schoeman v Constantia Insurance Company supra par 4-5; Duze v Auto \& General Insurance Co Ltd, unreported (D), (2006) 9 Juta's Insurance L Bul 136; JNG Express (Pty) Ltd v Botswana Insurance Co Ltd, unreported (Botswana CA), (2009) 12 Juta's Insurance L Bul 26.

41 Clarke Policies and Perceptions of Insurance Law in the Twenty-First Century 206.

42 Ibid.

43 Hornal v Neuberger Products Ltd [1957] 1 QB 247, 258 (CA).

44 Van Burren \& Co v Caledonian Insurance Co (1896) 3 Off Rep 52.

45 See fn 39 above.

46 32/2014 [2016] ZASCA 13. 
reasonable possibility of the loss eventuating and would therefore have taken reasonable steps to prevent same". ${ }^{47}$

The mere fact that there is for example an excessive claim for an amount more than the insured is entitled to, is not in itself proof of fraud nor does it create presumption of fraud; it may be a mere error made in good faith on the insured's part. ${ }^{48}$ The insurer will have to establish knowledge of the overstatement on the part of the insured and the required fraudulent intent by the insured. ${ }^{49}$ Such is the case where for example the insured's car gets broken into and then the insured starts adding items that were "stolen" from the vehicle when in fact these items were never even in the car. This would be an example of fraud on the part of the insured as it was their intent to defraud the insurer.

An important element of fraud in regard to fraudulent claims is the intention ${ }^{50}$ to deceive the insurer and to cause the insurer prejudice. ${ }^{51}$ Thus, the mere intentional act of the insured in, say, setting fire to his or her car, is not yet fraud. The intention to deceive the insurer is required. Therefore, if that same act is done with the intention of deceiving the insurer into paying out on an insurance policy for a loss for which it is not liable then the insured's conduct may be fraudulent for present purposes.

With that being said, while the intention to cause prejudice is required, actual prejudice is not. ${ }^{52}$ Potential prejudice is sufficient; there is therefore a fraudulent claim even if the insured's attempt to deceive the insurer was not successful as the insurer discovered or had been alerted to the fraud and therefore refused to meet the insured's claim. ${ }^{53}$ It is also stated that the prejudice itself need not be patrimonial. Thus, a false representation made by a policyholder which is intended to persuade an insurer to pay an insurance claim quicker, or without the investigations it would otherwise have made, may well suffice: the prejudice may simply lie in the fact that the conduct is seen to be contrary to the public interest. ${ }^{54}$

If an insured does claim fraudulently then this will have certain consequences for the insured. These consequences will generally lie in civil law, and may influence the validity or continued validity of his or her insurance contract with the insurer, or on his or her own liability for

\footnotetext{
Renasa Insurance Company Limited $v$ Watson supra par 45.

Schoeman v Constantia Insurance Company supra par 37.

Commercial Union Insurance Co of SA Ltd v Wallace 2004 (1) SA 326 (SCA); Santam Insurance Ltd v Africa Addressing (Pty) Ltd 2003 JOL 11584 (SCA); 20041 SA 326 (SCA).

52 Mngqibisa $v$ S 2008 (1) SACR 92 (SCA) (potential as opposed to actual prejudice sufficient and such prejudice to insurer shown by aim of insured to avoid higher excess being imposed on his claim; prejudice to insurer not too remote or fanciful; irrelevant to existence of fraud that insured had subsequently told insurer the truth as potential prejudice occasioned when false statement made in claim form).

53 Renasa Insurance Company Limited v Watson supra par 45. LAWSA XII Clauses dealing with Fraudulent Claims par 254 and 387.

54 LAWSA XII Clauses dealing with Fraudulent Claims par 254 and 387.
} 
damages, but can also in certain circumstances amount to the crime of fraud and render him or her liable to criminal prosecution. ${ }^{55}$

The issue of fraudulent claims is almost on every occasion dealt with by means of a fraudulent claim clause, such as a forfeiture clause. The common-law position has been settled - that is, the insured can derive no benefit from his/her fraudulent conduct. A forfeiture clause almost invariably seeks to confer rights - of forfeiture and cancellation - on insurers that they clearly do not have at common law. ${ }^{56}$ It is suggested that one of the reasons why there was no need for the introduction in our law of an implied term granting forfeiture rights on insurers in all cases where a claim is contaminated by fraud, is because insurers can relatively easily protect themselves. ${ }^{57}$

The general forfeiture clause provides that the insured will forfeit all benefits under the insurance contract if any part of his or her claim is in any respect fraudulent. ${ }^{58}$ Sometimes the insurer is also entitled to exercise a right of cancellation in terms of the insurance contract in such a case ${ }^{59} \mathrm{~A}$ clause providing for the forfeiture of benefits under the insurance contract enables the insurer in appropriate circumstances to recover from the insured the benefits it has mistakenly paid out in terms of the insurance contract. ${ }^{60}$

\section{$44 \quad$ Wording of forfeiture clauses}

In the Hiepner $v S A$ Eagle ${ }^{61}$ case, it was held that a valid claim for the actual loss of the insured motor vehicle accompanied by an allegedly fraudulent claim for loss of articles insured under a different section of same policy, had to be considered a single claim for purposes of the forfeiture provision in the fraudulent claim clause. And even an attempted fraud with a view to a claim and made before it was lodged is covered by a clause providing for forfeiture if fraudulent means or devices be used by the insured to obtain any benefit. ${ }^{62}$ The Hiepner case dealt specifically with fraud in a motor vehicle

Ibid.

Clarke Law of Insurance Contracts par 27.2C1.

5 Videtsky $v$ Liberty Life Insurance Association of Africa Ltd supra; Videtsky $v$ Liberty Life Insurance Association of Africa Ltd 1990 (1) SA 386 (W) 391; Schoeman v Constantia Insurance Company supra par 24.

58 Lehmbecker's Earthmoving \& Excavators (Pty) Ltd v Incorporated General Insurances Ltd supra 518-519 where the clause read as follows: "If any claim be in any respect fraudulent or intentionally exaggerated or if any fraudulent means or devices be used by the insured or anyone acting on his behalf to obtain any benefit under this policy or if any loss or damage be occasioned by or through the willful act or with the connivance of the insured all benefit under this policy shall be forfeited".

59 Normal remedies for breach of contract. Nagel Commercial Law.

60 Santam Bpk v Potgieter 1997 (3) SA 415 (O).

6120021 All SA 511 (W).

62 See Papagapiou v Santam Ltd, unreported (SCA), (2006) 9 Juta's Insurance L Bul 42, where the insured had offered the insurer's assessor money to inflate the damage to his property, an offer the assessor had refused but reported to the insurer. The Court pointed out that by virtue of the wording of the clause, the fraud had to be linked to the insured's 
insurance policy. This case shows how effectively a forfeiture clause can be used by the insurer when fraud takes place in the case of motor vehicle insurance.

The drafting of these forfeiture clauses once again becomes a pertinent issue. These clauses may be drafted in extremely wide terms, so as to cover the insurer in a more extensive sense, where they provide for the forfeiture of all benefits merely because the insured obstructed or impeded the insurer in the exercising of its rights; as is the case in English law. In the case of Santam Bpk $v$ Potgieter ${ }^{63}$ the forfeiture clause was widely drawn, and in this case the insurer relied on a fraudulently fabricated claim by the insured and was for that reason held not to be liable. However, the Court expressed the view $^{64}$ that even if the insurer had not been able to prove fraud on the part of the insured, the latter's failure to take reasonable steps to recover stolen insured property came within the clause and resulted in forfeiture. Our courts have generally given effect to the forfeiture provision contained in the fraudulent claim clause.

In another noteworthy case, that of South African Fire Insurance Co $v$ Dunstan $^{65}$ the fact that by virtue of a fraudulent claim clause in the contract the insured's fraudulently exaggerated claim resulted in the forfeiture of the insured's entire claim was not considered an unacceptable and hard result. The insurer, relying wholly upon the insured's good faith, was entitled to protect itself and its shareholders by an appropriate term in the contract, and insured had to bear the stipulated consequences of his own fraud. However, our courts have also questioned the acceptability of forfeiture of the whole claim where only part of it was fraudulent, suggesting that there may be other measures to prevent excessive claims by insured ${ }^{66}$ have said that a literal interpretation of forfeiture provisions such as those contained in fraudulent claim clauses "would produce startling results which could hardly have been intended", ${ }^{67}$ and have alluded to the need for legislative reform to alleviate the "harsh and inequitable consequences" of a forfeiture of indemnification in cases of breach of terms in insurance contracts relating to, for instance, fraudulent claims. ${ }^{68}$ This case seems to follow the approach as set out by Roman-Dutch law.

conduct, not (necessarily) his claim and accordingly upheld the insurer's decision not to pay the insured's otherwise valid claim.

63 Santam Bpk v Potgieter supra.

64 Santam Bpk $v$ Potgieter supra par 423-424. The Court's reliance on the principle of the utmost good faith in this regard seems misplaced; the insured after all was not proved to have acted fraudulently, in bad faith.

1984 (1) Off Rep 272.

66 Edwards $v$ London \& Lancashire Fire Insurance Co (1896) 17 NLR 18.

67 Springgold Investments (Pty) Ltd v Guardian National Insurance Co Ltd 2009 (3) SA 235 (D).

68 Napier v Van Schalkwyk 20043 All SA 346 (W); 2004 (3) SA 425 (W) 444. 


\section{Fairness of Forfeiture Clauses}

The fairness of forfeiture clauses is clearly a major concern. These clauses do tend to be somewhat one-sided, in that they generally aim at protecting the insurer. ${ }^{69}$ There should be a balance between the rights of the parties to an insurance contract. It must be mentioned that there is a specific provision contained within the FAIS General Code of Conduct that is aimed at protecting consumers. ${ }^{70}$ The Harikasun case ${ }^{71}$ will also be considered in order to discuss the impact of forfeiture clauses on the rights of the insured. The issue of fairness cannot be addressed without considering the Barkhuizen $v$ Napier ${ }^{72}$ case and the impact that this case had on the question of fairness of clauses contained within insurance contracts as well as the concept of pacta sunt servanda.

\section{Insurer's obligations in terms of the Financial Advisory and Intermediary Services $\mathrm{Act}^{73}$}

The most relevant section which applies to insurance contracts can be found in the General Code of Conduct (GCC) in terms of the Financial Advisory and Intermediary Services Act. ${ }^{74}$ Section 7(c)(vii) of the GCC states that financial service providers should provide a client, at the earliest possible opportunity, with full and appropriate information of, inter alia, "concise details of any special terms or conditions, exclusions of liability, waiting periods, loading, penalties, excesses or circumstances in which benefits will not be provided". It is clear that this section puts an obligation on the insurer's and intermediaries to bring any "onerous" clauses to the attention of the policyholder. Due to the fact that a forfeiture clause can be onerous to a policyholder, the GCC places an obligation on the insurer to inform the policyholder of such clauses so that they are aware of the existence of forfeiture clauses as well as the consequences which flow from them. This provision is far reaching in terms of bringing "onerous" clauses in line with what is fair for a consumer. It is therefore imperative that insurer's and intermediaries adhere to this clause. It is also submitted that such "onerous" clauses are brought to the attention of the policyholder again, specifically at claims stage so that they cannot say that they forgot about such clause which was only explained to them at the time of the conclusion of the contract, and as such attempt to put the blame on the insurer when a claim is brought forward.

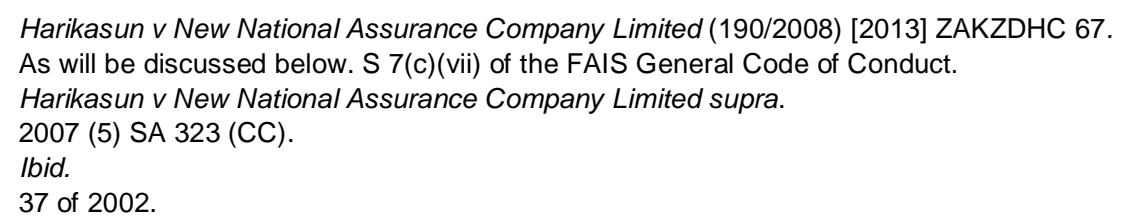




\section{The impact of the forfeiture clause in Harikasun $v$ New National Assurance Co Ltd for the insured}

In Harikasun $v$ New National Assurance Company Limited ${ }^{75}$ the plaintiff sought indemnification under an insurance policy issued by the defendant for loss suffered during an armed robbery at his home. ${ }^{76}$ The defendant, the insurer in casu, pleaded that the agreement of insurance was induced by the plaintiff's false representation that he owned and/or bore the risk of three items of jewellery which were included in the policy. ${ }^{77}$ However, it came to the attention of the insurer that those items were stolen prior to the inception date of the policy. ${ }^{78}$ The insurer acting as the defendant averred that as it extended insurance cover in respect of the three items relying on the plaintiff's misrepresentation, the policy was induced by fraud and the insurer was entitled to resile from the policy.

The second issue which the insurer also placed in dispute was the actual robbery and the theft of the items listed in the plaintiff's schedule of stolen goods. ${ }^{80}$ The insured, Harikasun, bore the onus of proving his loss, and the value thereof, on a balance of probabilities. ${ }^{81}$

With regard to the pre-contractual fraud, the insurer had the right to avoid the contract of insurance if the proposer had misrepresented a material fact or he had failed to disclose one. ${ }^{82}$ Based on the evidence, the Court found that Harikasun had established, on the probabilities, that the robbery at his residence did take place. ${ }^{83}$

In order to avoid liability under the policy, the insurer generally has to prove that there was pre-contractual fraud on the part of the plaintiff. ${ }^{84}$ Within that context, the misrepresentation must have materially affected the assessment of the risk under the policy at the time of issue before an insurer may avoid liability under the policy in terms of Section 53(1) of the Shortterm Insurance Act ${ }^{85}$. The Court was not persuaded that the contract of

(190/2008) [2013] ZAKZDHC 67.

Harikasun v New National Assurance Company Limited supra par 1.

Harikasun v New National Assurance Company Limited supra par 3.

Harikasun v New National Assurance Company Limited supra par 4.

Harikasun v New National Assurance Company Limited supra par 5.

Harikasun v New National Assurance Company Limited supra par 8.

Harikasun v New National Assurance Company Limited supra par 9.

Harikasun v New National Assurance Company Limited supra par 12.

Harikasun v New National Assurance Company Limited supra par 66.

Harikasun v New National Assurance Company Limited supra par 67.

53 of 1998, as amended by s 19 and 35 of the Insurance Amendment Act 17 of 2003. S 53 states the following: Misrepresentation and failure to disclose material information

(1)(a) Notwithstanding anything to the contrary contained in a short-term policy, whether entered into before or after the commencement of this Act, but subject to subsection (2) -

(i) The policy shall not be invalidated;

(ii) The obligation of the short-term insurer thereunder shall not be excluded or limited; and 
insurance was induced by fraud on the part of the plaintiff, which would otherwise entitle the defendant to avoid the policy. ${ }^{86}$

The third issue which the Court had to deal with was the issue of the plaintiff's misrepresentation for the cell phone that did work and was worth R4 500. The plaintiff deliberately tried to claim for a benefit that was not due to him. In addition, it was "fraudulent in the sense of having been made knowingly and with the intention of obtaining a benefit under the policy". ${ }^{87}$ In avoiding liability the defendant relied on clause 9 of the General Conditions of the insurance agreement, which provided that:

"If any claim under this policy be in any respect fraudulent or if any fraudulent means or devises be used by the Insured or anyone acting on his behalf to obtain any benefit under this Policy or if any accident, loss, destruction, damage or liability be occasioned by the wilful act or with the connivance of the Insured all benefit under this Policy shall be forfeited."

The Court found that the plaintiff's fraudulent claim in respect of the cell phone, constituted a breach of the conditions of the policy with the result that the defendant was entitled to avoid the claim. ${ }^{89}$ The Court dismissed the plaintiff's claim. However, the fraudulent claim by the plaintiff, for the cell phone, resulted in the Court making an adverse costs order against him. ${ }^{90}$

This case clearly shows the adverse position that the insured is in when an insurance contract contains a forfeiture clause. The problem with these clauses is that they can result in an entire claim being forfeited when only a small portion of the claim is fraudulent. With that being said, it is, however, necessary that an insurer have mechanisms in place to protect themselves from fraudulent conduct. The forfeiture clause does, however, seem to be unnecessarily harsh in instances when only a small portion of a claim is fraudulent and the rest of the claim is valid. An insured stands to forfeit an entire claim when only a portion of the claim is fraudulent, it is for this reason that it is submitted that the Short-term Policyholder Protection Rules include a rule on fraud-related clauses such as forfeiture clauses. The PPR's can

(iii)The obligations of the policyholder shall not be increased, on account of any representation made to the insurer which is not true, or failure to disclose information, whether or not the representation or disclosure has been warranted to be true and correct, unless the representation or non- disclosure is such as to be likely to have materially affected the assessment of the risk under the policy concerned at the time of its issue or at the time of any renewal or variation thereof.

(b) The representation or non-disclosure shall be regarded as material if a reasonable, prudent person would consider that the particular information constituting the representation or which was not disclosed, as the case may be, should have been correctly disclosed to the short- term insurer so that the insurer could form its own view as to the effect of such information on the assessment of the relevant risk. See also Harikasun v New National Assurance Company Limited supra par 67.

86 Harikasun v New National Assurance Company Limited supra par 73.

87 Par 90.

88 Par 91

89 Par 92

90 Harikasun v New National Assurance Company Limited supra par 92 and 93. 
spell out exactly how these clauses should be implemented and used in order to bring about a more equitable outcome for both the insurer and the insured. The PPR's can state that while forfeiture clauses have a place in our law, they should be brought in line with the concept of fairness for both parties.

\section{Principle of pacta sunt servanda and the Constitutional Court's decision in Barkhuizen $v$ Napier}

The principle of pacta sunt servanda ${ }^{91}$ transports the idea of certainty and implies that a party to a contract should be able to rely on the other party to keep their contractual promise. However, as was seen in Barkhuizen $v$ Napier, ${ }^{92}$ insurance contracts may contain clauses that have negative consequences for policyholders. It is usually only when aggrieved policyholders are faced with such clauses that the debate turns to the fairness of these clauses. ${ }^{93}$ In this case, the Constitutional Court had to rule on the validity of time bar clauses. The majority of the Court held that public policy requires parties to comply with contractual obligations undertaken freely and voluntarily, therefore reinforcing the rule of pacta sunt servanda. ${ }^{94}$ It was after this judgment that the legislature intervened and formulated new rule 7.4 of the Policyholder Protection Rules (PPR's) in terms of the LongTerm Insurance Act ${ }^{95}$ and the Short-term Insurance Act. ${ }^{96}$ The new rule states that as from 1 January 2010, any time limitation provision may not include the 90-day period within which the insured may make representations to the insurer, and it must provide for a period of not less than six months after the expiry of the 90-day period for the institution of legal action. It goes on further and says that even in cases where the time bar period has expired, the policyholder may request the court to condone non-compliance if the court is satisfied that "good cause" exists for the failure to institute legal proceedings, and "that the clause is unfair to the policyholder". ${ }^{97}$

\section{An analysis of whether the call for reform in Napier NO $\checkmark$ Van Schalkwyk should be revisited}

In Napier NO $v$ Van Schalkwyk $k^{98}$ the Court found that a requirement to report damage to a vehicle within 24 hours of the accident was clear and

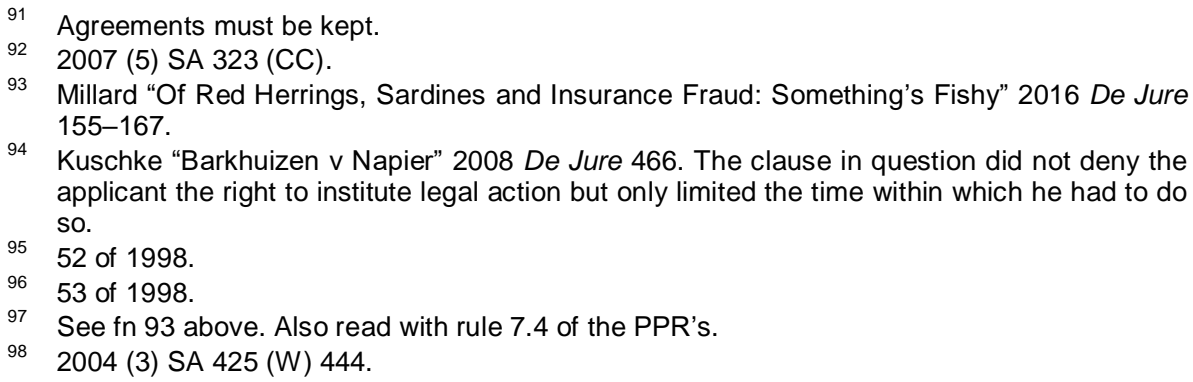


unequivocal in its meaning and effect and the breach absolved the Lloyd's insurer from liability. ${ }^{99}$ Boruchowitz $J$ wrote a separate judgment, commenting that the facts of the case underscored the need for legislative reform along the lines of Canadian legislation enacted to relieve an insured of the consequences of forfeiture. ${ }^{100}$ With regards to the validity of forfeiture clauses, these have not yet been successfully challenged in a South African court. However, a clear call for legislative reform was called for in the Napier case. ${ }^{101}$ It is thus suggested that the call for reform should be revisited by the legislature. The call for reform should, however, keep in mind the different positions in terms of English law, where forfeiture clauses are valid and enforceable, and that of our common law which does not have a penal nature. ${ }^{102}$ The reforms should be brought in line with the concept of fairness and striking a balance between the rights of both parties.

\section{RECOMMENDATIONS}

Due to the fact that forfeiture clauses can lead to inequitable results, especially in cases where only a small portion of the claim is fraudulent, it is necessary to bring in some needed clarity on the application of these clauses. There is definitely a place for forfeiture clauses in our law, but there is a need for reform on the current laws regarding forfeiture clauses and fraudulent claims. Firstly, the Short-term Insurance Policyholder Protection Rules should regulate fraud-related clauses, such as forfeiture clauses, in order to bring about some legal certainty on these clauses and to bring them in line with the concept of fairness. ${ }^{103}$ The rules can help bring clarity on the much needed issue of the application of forfeiture clauses as well as state that if an insurance contract does contain a forfeiture clause then this clause should be brought to the attention of the policyholder specifically at claims stage. It is suggested that insurers follow the following procedure; Firstly, a client should be notified whether there is a forfeiture clause in his insurance contract and if there is, that clause should be put to him. Secondly, the client should be notified as to the scope of the fraudulent clause, in other words, which actions by the client may possibly be identified as fraudulent and importantly, what the consequences of such actions will be. Finally, a client should be made aware of the fact that the insurance company may investigate the claim with a view to invoking such a clause. In the final instance, it is submitted that fraud clauses are necessary but that the need for these clauses should be brought into balance with the rights of policyholders.

Going back to the call for reform which was suggested in the Napier case, it is recommended that such a reform should be dealt with in order to bring some certainty on the position of forfeiture clauses. It is suggested that this

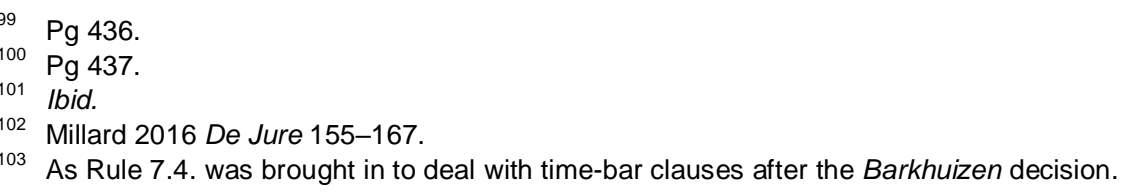


reform can take place through the PPR's which can bring forfeiture clauses in line with public policy and fairness, as with the case in Barkhuizen, which introduced rule 7.4 in the PPR's dealing with time-bar clauses. A similar provision on forfeiture clauses is recommended to be included in the PPR's.

\section{CONCLUSION}

Using forfeiture clauses as a preventative measure against insurance fraud seems to be an effective mechanism for insurers. The reason for this is that these forfeiture clauses protect the interests of the insurer by providing them with an effective mechanism to escape liability when the insured fraudulently claims against the insurer. These clauses have proven to be effective as seen in the cases of Harikasun $v$ New National Assurance Company Limited $^{104}$ and Lehmbecker's Earthmoving \& Excavators (Pty) Ltd $v$ Incorporated General Insurances Ltd. ${ }^{105}$ However, they are also seen as being unfair and too harsh towards the policyholder.

Due to the fact that fraud is so prevalent in motor vehicle insurance claims, it is pertinent that insurers have mechanisms in place to protect them. Contractual provisions such as forfeiture clauses are good examples of how insurers can protect themselves from fraudulent claims by the policyholders. The current position of preventative measures to be used by insurers in such cases needs urgent attention. There needs to be a clear position in terms of the law of how to regulate fraudulent claims. Currently, there is some confusion as to whether the insurer can forfeit the entire claim or only the fraudulent part of the claim and clarity is needed in this regard. It is clear that forfeiture clauses are effective, if worded correctly, and can curtail fraud by a policyholder. It is due to this reason that it is suggested that the PPR's be used to regulate the proper implementation of these clauses. The PPR's can provide some much needed clarity on the application of forfeiture clauses by following the procedure as mentioned in the recommendations above. This would bring in an element of fairness towards the policyholder and thus result in a better balance for rights between the contracting parties.

It is however submitted that in line with the growing trend to use fairness as a measure, a prospective insured should be made aware of the existence of a forfeiture clause before the contract of sale is concluded and then again, at claims stage. In such a case, the policyholder would then definitely be aware of such a clause and the consequences of submitting a fraudulent claim. A forfeiture clause should be used to ensure that a client such as the one in the Harikasun case is in fact brought to book. It should however not be used as a tool to discourage honest claims and to that end, it is suggested that insurers should incorporate certain standard procedures specifically at claim stage.

104 (190/2008) [2013] ZAKZDHC 67.

10519842 All SA 352 (A). 